\title{
A Festa da Jaguatirica: uma partitura crítico-interpretativa
}

\author{
Victor Marques de Araujo' \\ Mestrando em Antropologia Social do PPGAS/UFMT
}

MENEZES BASTOS, Rafael José de. A festa da jaguatirica: uma partitura crítico-interpretativa. Florianópolis: Editora da UFSC, 2013. 524 pp. CD anexo.

Defendida em 1990 na Universidade de São Paulo a tese de doutorado de Rafael José de Menezes Bastos, A Festa da Jaguatirica: uma partitura críticointerpretativa, já se tornou um clássico. O trabalho de campo começou em 1981 e, entre idas e vindas, somou vinte e seis meses. Contudo, a escrita do trabalho começou apenas em 1985, em Santa Catarina.

Já no capítulo 1, o autor mostra o contexto do qual o livro faz parte. Fruto de discussões amplas sobre a definição do campo e do próprio objeto da música sendo lançado como parte de uma ciência, a Etnomusicologia, a intenção do

1 Pesquisador do Núcleo de Artes, Performance e Simbolismo (Napas) e do Núcleo de Antropologia e Saberes Plurais da UFMT. 
pesquisador é juntar a parte musicológica - os sons, os ritmos, cânticos - e o aspecto do comportamento, que ele afirma como cultural, da seara da antropologia. Trata-se do dilema - paradoxo - etnomusicológico, sobre como fazer dialogar música, som, e contexto, comportamento:

\begin{abstract}
Um camaleão, o etnomusicólogo: músico entre os antropólogos, e vice-versa, o que lhe permite - para longe de uma mera pulsação entre falsa consciência e prática apropriar-se de recursos aqui e ali ao mesmo tempo. Esta, a sua mercabilidade, instrumental daquela do mercado de "música dos outros" que intermedeia, mercado este que o que vende são identidades. Neste mercado, enfim, a racionalidade tanto das separações quanto das uniões entre Etnomusicologia, Música e Antropologia (Menezes Bastos, 2013: 55).
\end{abstract}

Camaleão na profissão e no texto, o projeto do autor segue no sentido de uma Semântica Musical, a partir da qual, em um pano de fundo musical relacionado ao de expressão, ele objetiva delimitar o que é sentido e o que é contexto, buscando a música como linguagem, completa com significantes e significados. O paradoxo reaparece no entendimento da música enquanto música e da música enquanto cultura, estando de qualquer maneira a música na interseção entre cultura e som, e a Etnomusicologia, como produto único e novo de outras áreas, como da Musicologia Comparada, Musicologia História, PsicoMusicologia, etc., como a ciência que estuda aquele paradoxo: "a Etnomusicologia não é uma soma, mas uma construção original” (Menezes Bastos, 2013: 57).

Fazendo a história da disciplina e um resumo de diversos autores que lidam com o tema próprio da música, de outras áreas que estudam a música e da Etnomusicologia, Menezes Bastos defende que a música não é uma expressão de algo meramente musical. Entende a música como histórica e culturalmente localizada em uma sociedade específica, Menezes Bastos coloca a música no plural, multivocal e multiagenciada, pois não há uma única expressão musical que prevalece em qualquer lugar. E também entende a música vinculada aos comportamentos que não são nem sua causa, nem sua consequência: são uma parte da expressão do outro, ou seja, a música no comportamento e o comportamento na música.

Por fim, a Música Ocidental assim aparece como um sistema sociocultural específico, em relação a que músicas exóticas, segundo o autor, são colocadas, incluídas as etnocentricamente chamadas de "primitivas". A Música Ocidental, construída, apresenta como características básicas a monumentalidade, o progresso, a interioridade e a universalidade, sendo um sistema que procura disciplinar os aspectos da sensibilidade através da técnica capaz de ser entendida, e um sistema que é produto dos grandes "gênios" e civilizado: em última análise, europeu. Assim, o resultado é que a Música Ocidental, "operando em dois movimentos cumulativos, produz, de um lado, a distinção "nós/outros", de outro, elaborando internamente a ocidentalidade europeia" (Menezes Bastos, 2013: 85), ideia que atravessa o livro como um todo.

Enquanto o primeiro capítulo organiza historicamente e teoricamente os campos da Etnomusicologia, o capítulo 2 aparece como o primeiro diferencial do texto. O próprio autor diz que replicou integralmente o material Yawari colhido em Junho de 1984, dividindo a descrição em três partes: Antecedentes, onde são colocadas as consultas entre Wahu e Takumã para a realização do ritual; Intratribal, que começa com o ritual Yawari até seu término; e Intertribal, com a relação entre os anfitriões kamaiurá e os visitantes maku. O capítulo é cheio de descrições a respeito do ritual musical, sendo reservada a análise ao capítulo 3 . 
Segundo diferencial do texto, o terceiro capítulo comenta o sistema cancional Yawari, apresentado etnograficamente no capítulo 2. Os comentários se dão em três níveis:

\begin{abstract}
O primeiro refere-se ao cântico per se. O segundo, às sequências individualmente. $O$ terceiro admite três níveis: o das sequências homólogas (primeiro nível), o atinente à integralidade do sistema (macro) $e$ - no estudo das sequências contínuas (aquelas que somam sequências de vários tipos, cantadas continuamente) - o relativo à totalidade das sequências noturnas (quase macro). Os comentários agrupam-se em duas partes. A primeira aborda a ordenação articulatória dos planos sequencial $e$ intersequencial. A segunda, a constituição tonal e motívica de seus cânticos e de suas sequências (sequencial). Essa constituição abarca os planos de expressão e de conteúdo da música. Subsidiariamente, os comentários tematizam as letras do sistema” (Menezes Bastos, 2013 : 197).
\end{abstract}

Os dois capítulos apresentam o sistema cancional em dois momentos: um etnografado com a reprodução total do material coletado e outro de análise sobre o anterior. Em que pese a qualidade detalhada do trabalho, a reprodução completa do sistema musical apresenta ao leitor comum e sem conhecimento de teoria musical alguns problemas de compreensão. Toda a análise se dá em uma marca de música. A descrição etnográfica e seus comentários são construídos a partir da linguagem musical, ficando as descrições acerca do parentesco, embora contínuas às musicais, menores no sentido da conexão com a própria música, menores em volume de texto. O ponto central do autor é, contudo, claro: "Meu modelo, pois, é substancialista quanto à ordem fonológica da música” (Menezes Bastos, 2013: 410).

No capítulo 4 o autor retoma o tom mais fácil aos não iniciados em teoria musical. Para o autor, o sistema musical Yawari é complexo, múltiplo e culturalmente determinado. As escalas são constituídas de tons, ou, como ele diz, tensões que se direcionam para um centro tonal que seria, no sistema Yawari, a "summa estrutural" do próprio sistema. Ao contrário Música Ocidental, no sistema Yawari o centro tonal não é um espaço de relaxamento: é "o tônus dos vivos", da ativação. As escalas são construções culturais que foram elaboradas diferentemente no sistema descrito, onde tons, notas, sons e todo o sistema é articulado com novos valores.

Relacionado ao ritual, a música é corporificada, com a letra existindo dentro da música e, esta, dentro dos corpos que dançam nos rituais. Mito, música e dança são "tautegorias": "Elas desenham esforços de expressão significante de significados antecessores, para estes acenando através de novos significados, consequentes" (Menezes Bastos, 2013: 427). São três vetores que se complementam ao mesmo tempo que se suplementam, criando um jogo entre significantes e significados que constroem a lógica e a ativação ritual do sistema como um todo.

Por último, o ritual descrito vincula-se ao parentesco apontando na direção de uma fusão do grupo unilocal: "unilocalidade esta, entretanto, sempre triangulada, na singularidade, sempre opositiva na pluralidade" (Menezes Bastos 2013: 453). O ponto mais importante é que Bastos faz seu estudo construindo dois universos: um ético, onde estão os personagens e suas relações em função do mito; e outro da música, que ambienta o que as letras representam, posto que as letras vão dentro da música e o ritual vai dentro da dança, no sistema nativo. Costume e música se organizam entre si, se correspondem em um plano cosmológico, se ligando de forma estrutural.

Por fim a obra revela uma etnografia de caráter bilateral, onde "nós" e os “outros” temos nossas posições colocadas em xeque. É uma via de mão dupla, 
onde paradigmas podem ser descobertos de ambos os lados. Numa observação que transcende a mera análise musicológica, mergulha-se numa pesquisa que desvenda fatos sobre a cosmologia e a sociedade indígena em questão através de agenciamentos políticos amazônicos. O estudo de sua sintaxe e gradação linguística revela além do que, a princípio, um estudo musicológico pode parecer querer revelar ao leitor. Portanto, de uma natureza poeticamente surpreendente a obra reforça o caráter decodificador dos povos xinguanos, o que se pode esperar da amplitude e ressonância da ciência antropológica e seu elo com a contemporaneidade poética, dinâmica e social de diversos povos.

Recebido em 20/11/2016.

Aprovado em 26/12/2016. 